\title{
Comparison of Chamcham manufactured from cow milk and buffalo milk
}

\author{
M. A. Haque ${ }^{1}$, M. H. Rashid ${ }^{2}$, M. F. I. Kajal ${ }^{3}$ and M. S. Istiak ${ }^{4}$ \\ $1,2,3$ Department of Dairy Science, ${ }^{4}$ Department of Poultry Science, Bangladesh Agricultural University, Mymensingh- \\ 2202, Bangladesh, E-mail:anam.bau@gmail.com
}

\begin{abstract}
This experiment was conducted to study quality of Chamcham manufactured from cow milk and to compare it with Chamcham manufactured from buffalo milk and mixture of cow and buffalo milk. Three types of Chamcham were prepared from cow milk(A), buffalo milk(B) and $50 \%$ cow $+50 \%$ buffalo milk(C). In this experiment the quality of prepared Chamcham were evaluated with the help of chemical test. The moisture, total solids, protein, fat, ash and carbohydrate contents of cow milk and buffalo milk Chamcham were showed significant differences $(p<0.01)$ except acidity and $\mathrm{pH}$ content. Results showed that chamcham manufactured from buffalo milk was superior to that of cow milk chamcham and 50\% cow $+50 \%$ buffalo milk chamcham.
\end{abstract}

Keywords: Comparison, Chemical components, Chamcham, Cow milk, Buffalo milk

\section{Introduction}

From nutritional point of view milk is not only the most important food for new born child but also for adolescents, adults, invalids, convalescents and patients. Hence milk is converted to various milk products. About $10 \%$ of the total milk produced in Bangladesh are used for the preparation of Chhana and finally for sweetmeat making (Government forth plan study, 1998). The sweetmeats that are available in the markets are mostly Chhana-based milk products and palatable food. Sweetmeats have a significant role in our culture. The available milk sweetmeats in the markets of Bangladesh are Chamcham, Rasogolla, Malaikari, Kalojam, Sandesh, Kachagolla, Rassokadam, Peda, Rajvog, Amirti, Sanar polao, Monda, Pantoa and Misti Dahi. Out of different types of sweetmeats chamcham is one of the most popular.

Since, Chamcham is a Chhana based sweetmeat, it is very nutritious for accounts of its fairly high protein and fat content, minerals specially calcium and phosphorus and also for fat soluble vitamins, particularly vitamin $A$ and $D$ content. Chamcham is being produced traditionally throughout Bangladesh. It consists of mainly of three components namely small ball which is made by the fresh prepared Chhana, sugar syrup where balls are put gently to heating and raw milk by boiled up to light brown colour. Generally, Chamcham is made from cow milk, but the quantity of cow milk is not satisfactory round the year in our country. The scarcity of milk hampers the production of sweetmeats as well as Chamcham, which contributes in the rise of price.

In India nearly half of the milk processed by organized dairies comes from buffaloes (Aneja, 1990). In Bangladesh buffalo milk is one of the important sources of milk.In our country total milk production from cattle and buffaloes were7 82,000 and 24,000 MT respectively (FAO, 1997). So, buffalo milk could be used for the preparation of sweetmeats. Buffalo milk contains higher peroxidase than cow milk, which acts as a natural preservative. Saturated fatty acids are higher in buffalo milk which results in lower iodine value to the fat. Buffalo milk contains greater proportion of casein and is slightly higher in albumin and globulin. Although buffalo milk is an excellent source of fat and protein but no effort has been made to utilize buffalo milk for the preparation of Chamcham. That is why, the present study was carried out to monitor the chemical components of Chamcham made from buffalo milk and also to make a comparison between Chamcham made from cow milk and buffalo milk. 


\section{Materials and Methods}

This experiment was conducted at the Dairy Chemistry and Technology Laboratory, Bangladesh Agricultural University, Mymensingh during the period of January 1, 2012 to May 5, 2012. Part of the chemical analyses were done at the Dairy Chemistry and Technology Laboratory and the rest at the Central Laboratory of Bangladesh Agricultural University, Mymensingh. The experiment was carried out to evaluate the chemical components of chamcham made in the laboratory from cow and buffalo milks.

\section{Preparation of Chamcham}

Collection of Milk: For the preparation of Chamcham cow milk was collected from Bangladesh Agricultural University Dairy Farm and buffalo milk was collected from Senbari bazaar, Trishal, Mymensingh. Before making Chhana the milk samples were analyzed in the Laboratory to know their Fat and SNF content.

\section{Ingredients used for the preparation of Chamcham}

\section{Chamcham manufactured from Cow milk}

The ingredients used to make $1.5 \mathrm{~kg}$ of Chamcham are given below:

Whole milk $=3$ Litre

Sugar $=2 \mathrm{~kg}$ (to prepare sugar syrup)

Flour $=40 \mathrm{~g}$ (1\% of wt. of Chhana)

Sour whey $=500 \mathrm{ml}$

Two Litres of milk were used for Chamcham preparation and one litre milk was used for Mawa preparation.

\section{Chamcham manufactured from Buffalo milk}

The ingredients used to make1.5 $\mathrm{kg}$ chamcham are given below:

Whole milk $=3$ Litre

Sugar $=2 \mathrm{~kg}$ (to prepare sugar syrup)

Flour $=40 \mathrm{~g}$ ( $1 \%$ of wt. of chhana)

Sour whey $=500 \mathrm{ml}$

Two litre milk was used for Chamcham preparation and one litre milk was used for Mawa preparation.

\section{Chamcham manufactured from $\mathbf{5 0 \%}$ cow and $\mathbf{5 0 \%}$ buffalo milk}

Whole milk = 3 Litre (1.5 litre cow milk and 1.5 litre buffalo milk)

Sugar $=2 \mathrm{~kg}$ (to prepare sugar syrup)

Flour $=40 \mathrm{~g}$ ( $1 \%$ of wt. of Chhana)

Sour whey $=500 \mathrm{ml}$

Two litre milk was used for Chamcham preparation and one litre milk was used for Mawa preparation.

\section{Preparation of Chhana}

During each trial 3 litres of cow milk, 3 litres of buffalo milk and 1.5 litre cow milk plus 1.5 litre of buffalo milk were used for the preparation of Chhana for 3 types of Chamcham named $A, B$ and $C$ respectively. At first the milks were heated to $90^{\circ} \mathrm{C}$ in three separate iron pans. After heating the milks were cooled to $80^{\circ} \mathrm{C}$ and sour whey was added until Chhana separated. The contents were allowed to cool down at room temperature (about $25-29^{\circ} \mathrm{C}$ ). After 30 minutes the Chhana and whey mix was transferred to 3 pieces of muslin cloth. When whey was completely drained out, the Chhana was hung for about one hour for complete drainage of whey. Then the Chhana was carefully removed from the muslin cloth and weighed. In total $600 \mathrm{~g}, 500 \mathrm{~g}$ and $200 \mathrm{~g}$ of Chhana was obtained from $3 \mathrm{~L}$ of fresh cow milk, $3 \mathrm{~L}$ of fresh buffalo milk and $3 \mathrm{~L}$ of $50 \%$ cow and $50 \%$ buffalo milk respectively. 


\section{Preparation of Chamcham}

The mass of Chhana was broken and kneaded with wheat flour ( $1 \%$ of the volume of Chhana) in order to obtain the desired body and texture. Small balls were made without cracks. Concentrated sugar syrup (sugar: water $=1.5: 1$ ) was made and heated to boiling. Just after boiling the scum was ladeled out to obtain a clear syrup. Then the balls of Chhana were cooked in the boiling sugar syrup for 45 minutes, then cooled to room temperature.

\section{Preparation of Mawa}

Milk was boiled to drying for the preparation of Mawa. Raw Chamcham were separated from sugar syrup, arranged on trays and mawa was spread on the balls to garnish the Chamcham.

\section{Chemical analysis}

Chamcham made in the Laboratory from cow and buffalo milk were analyzed for moisture, total solids, protein, fat, carbohydrate and ash following AOAC (2003) method. Acidity was determined by the titrating with N/10 sodium hydroxide solution using the procedure of Aggarwals and Sharma (1961).

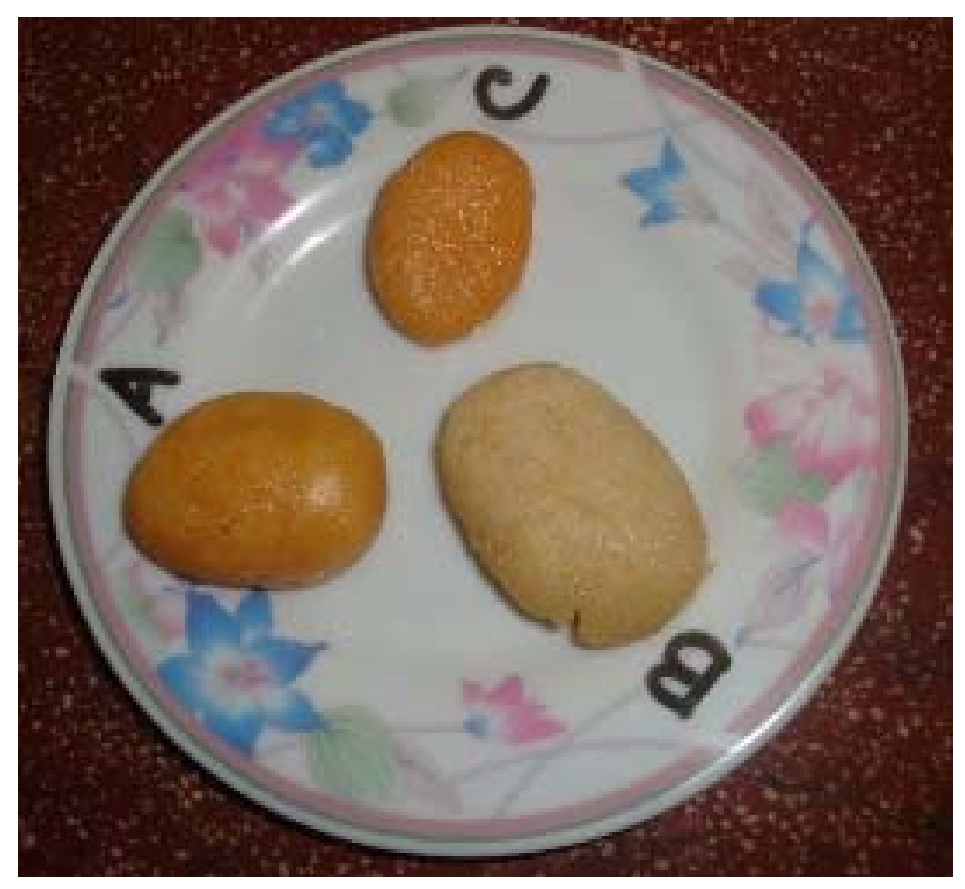

Photograph: Representation of different types of Chamcham

$A=$ Chamcham manufactured from Cow milk

$\mathrm{B}=$ Chamcham manufactured from Buffalo milk

$C=$ Chamcham manufactured from $50 \%$ Cow milk $+50 \%$ Buffalo milk 
Schematic diagram for the preparation of Chamcham

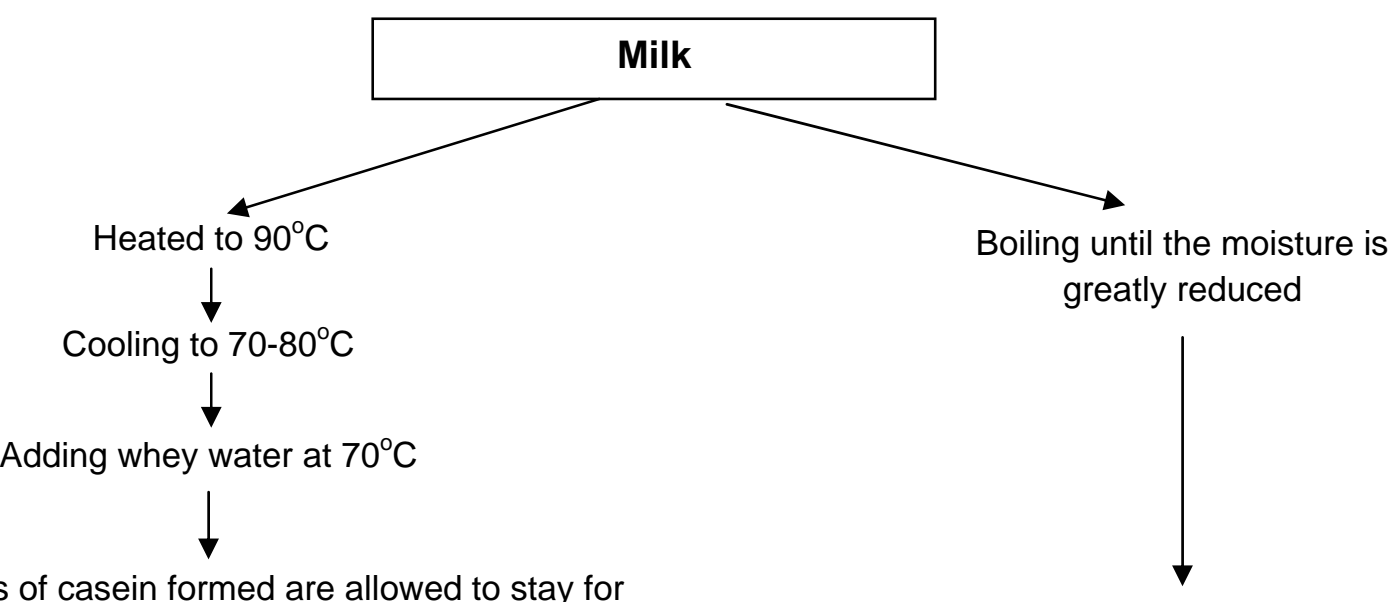

The lumps of casein formed are allowed to stay for few minutes for complete of Channa

Cooling to room temperature

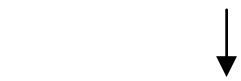

Filtering through muslin cloth

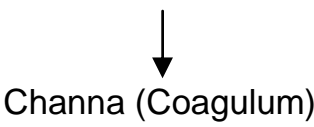

Grinding
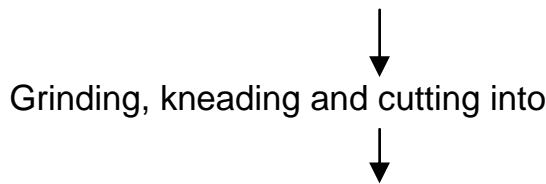

Kneading of Channa with flour of subsequent preparation into ball<smiles>[13CH3]</smiles>

Preparing and boiling of sugar syrup

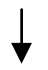

Dropping of Channa balls (20-25 pieces)

in the boiling syrup

$\downarrow$

Cooking for 40-45 minutes (during cooking sprinkling of cold water)

$\downarrow$

Cooling at room temperature for 3-4 hours

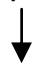

Separation of balls from the sugar syrup

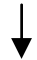

Spreading of Mawa over the balls

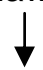

\section{Chamcham}




\section{Design of the experiment and Statistical analysis}

The experiment was conducted following Completely Randomized Design (CRD). Data collected for different parameters were subjected to statistical analysis using MSTAT Statistical Programme.

\section{Results and Discussion}

Chamcham was prepared in the Laboratory from cow milk and buffalo milk. The prepared Chamcham samples were designated as A (cow milk) and B (buffalo milk) and C (both cow and buffalo milk). The results of various chemical parameters of Chamcham samples are presented and discussed in this chapter.

Chemical parameters: The different samples of Chamcham were analyzed for their contents of moisture, total solids, protein, fat, carbohydrate and ash, acidity and $\mathrm{pH}$. The results are presented in Table 1.

Table 1. Comparison of average composition of three different types of Chamcham

\begin{tabular}{|c|c|c|c|c|c|}
\hline \multirow{2}{*}{ Parameters } & \multicolumn{3}{|c|}{ Types } & \multirow{2}{*}{$\begin{array}{l}\text { LSD } \\
\text { Value }\end{array}$} & \multirow{2}{*}{$\begin{array}{c}\text { Level of } \\
\text { Significance }\end{array}$} \\
\hline & $A$ & $B$ & $\mathrm{C}$ & & \\
\hline Moisture $(\mathrm{g} / \mathrm{kg})$ & $536.42^{a} \pm 1.51$ & $458.00^{\mathrm{C}} \pm 2.00$ & $477.67^{b} \pm 2.52$ & 6.204 & ** \\
\hline Total solids $(\mathrm{g} / \mathrm{kg})$ & $463.58^{\mathrm{C}} \pm 1.51$ & $542.00^{\mathrm{a}} \pm 2.00$ & $522.33^{b} \pm 2.52$ & 6.204 & ** \\
\hline Protein $(\mathrm{g} / \mathrm{kg})$ & $61.67^{\mathrm{C}} \pm 0.76$ & $85.00^{\mathrm{a}} \pm 1.00$ & $72.17^{b} \pm 1.04$ & 2.854 & ** \\
\hline Fat $(\mathrm{g} / \mathrm{kg})$ & $73.75^{c} \pm 1.39$ & $120.92^{\mathrm{a}} \pm 2.74$ & $98.08^{b} \pm 0.95$ & 5.623 & ** \\
\hline Carbohydrate $(\mathrm{g} / \mathrm{kg})$ & $311.87^{b} \pm 1.69$ & $316.92^{b} \pm 1.08$ & $334.68^{a} \pm 2.72$ & 5.902 & ** \\
\hline Ash $(\mathrm{g} / \mathrm{kg})$ & $9.37^{\mathrm{C}} \pm 0.15$ & $12.25^{a} \pm 0.25$ & $10.50^{b} \pm 0.50$ & 1.013 & *夫 \\
\hline Acidity (\%) & $0.230 \pm 0.02$ & $0.213 \pm 0.03$ & $0.200 \pm 0.01$ & & NS \\
\hline $\mathrm{pH}$ & $6.70 \pm 0.10$ & $6.70 \pm 0.10$ & $6.70 \pm 0.10$ & & NS \\
\hline
\end{tabular}

Different superscripts in the same row differ significantly

** = Significant at $1 \%$ level

NS = Not Significant

$A=$ Chamcham manufactured from cow milk

$\mathrm{B}=$ Chamcham manufactured from buffalo milk

$C=$ Chamcham manufactured from $50 \%$ cow milk $+50 \%$ buffalo milks

Moisture content: The average moisture content of Chamcham samples A, B and C were $536.42 \pm 1.51$, $458.00 \pm 2.00$ and $477.67 \pm 2.52 \mathrm{~g} / \mathrm{kg}$ respectively (Table). Significant difference $(p<0.01)$ was found in moisture content of the samples. Higher moisture content was noticed in sample $A$ and lower moisture content was found in sample B. The higher amount of moisture indicates good quality Chamcham and sometimes it might give good flavor in the products whereas Chhana containing 62.5 and $63.5 \%$ moisture. Gupta et al. (1993) stated that overall textural quality was significantly correlated with moisture.

Total solids: The total solids content of samples A, B and C type of Chamcham were 463.58 \pm 1.51 , $542.00 \pm 2.00$ and $522.33 \pm 2.52 \mathrm{~g} / \mathrm{kg}$ respectively (Table 1 ) . Statistical analysis showed that there were significant difference among the total solids content of different types of Chamcham $(p<0.01)$. From the Table 1 it is found that type B had the highest total solids contents and the lowest in case of A type Chamcham. The variation in total solids content was due to the variation in the moisture content of Chamcham, and which gradually increased due to the use of buffalo milk Chhana in greater proportions.

Protein content: The average protein content of A, B and C type Chamcham were $61.67 \pm 0.76$, $85.00 \pm 1.00$ and $72.17 \pm 1.04 \mathrm{~g} / \mathrm{kg}$ respectively (Table 1 ). Statistical analysis showed that there was significant difference $(p<0.01)$ among the protein contents of different sample. It was found that use of buffalo milk Channa enhanced the protein content of Chamcham because buffalo milk contains higher percentage of protein as compared to cow milk. So, B type chamcham had the higher protein because it was prepared exclusively from buffalo milk in contrast, A type chamcham had the lower protein content because it was from cow milk. 
Fat content: The average fat contents of A, B and C type Chamcham were $73.75 \pm 1.39,120.92 \pm 2.74$ and $98.08 \pm 0.95 \mathrm{~g} / \mathrm{kg}$ respectively (Table 1 ). Statistical analysis showed that there was significant difference $(p<0.01)$ among the fat content of different types of Chamcham sample. It was observed that the sample $B$ had the highest fat content and sample $A$ had the lowest fat content among the three samples. The fat content of sample $\mathrm{C}$ followed sample $\mathrm{B}$. The variation of fat content in different Chamcham samples might be due to buffalo milk Chhana, because buffalo milk contains more fat than cow milk.

Carbohydrate content: The average carbohydrate contents of A, B and C type Chamcham were $311.87 \pm 1.69,316.92 \pm 1.08$ and $334.68 \pm 2.72 \mathrm{~g} / \mathrm{kg}$ respectively (Table 1 ). Statistical analysis showed that there were significant difference in carbohydrate content of different types of Chamcham $(p<0.01)$. It was observed that all types of Chamcham high carbohydrate contents because carbohydrate content of Chamcham sample depends upon the addition of sugar and starchy materials like wheat flour.

Ash content: The average ash contents of A, B and C type of Chamcham were $9.37 \pm 0.15,12.25 \pm 0.25$ and $10.50 \pm 0.50 \mathrm{~g} / \mathrm{kg}$ respectively (Table 1$)$. There was significant difference $(p<0.01)$ among the ash content different samples. It was observed that the different types of chamcham had the similar ash content. The chamcham which contented higher amount of total solids might have higher levels of ash. Katra and Bhargava(1990) said higher ash and total carbohydrate decrease the sponginess.

Acidity percentage: The acidity percentage of different types of Chamcham samples were shown in (Table 1). It was found that the average percentage of acidity for A, B and C type of chamcham were $0.23 \pm 0.02,0.21 \pm 0.03$ and $0.20 \pm 0.01$ respectively. Statistical analysis showed that there was no significant difference. The acidity content of the samples were mostly due to protein. Arora et al. (1995) reported that the lactic acidity was increased during the storage.

pH content: The average pH values of different types of Chamcham samples were shown in Table $1 \mathrm{It}$ was found that the average $\mathrm{pH}$ for $\mathrm{A}, \mathrm{B}$ and $\mathrm{C}$ type Chamcham were 6.70 $\pm 0.10,6.70 \pm 0.10$ and $6.70 \pm 0.10$ respectively. Statistical analysis showed that there was no significant difference among different types of Chamcham sample.

\section{Conclusion}

Attempts should be made to popularize buffalo milk Chamcham throughout the country and suggest appropriate technology with specific proportion of ingredients for making good quality chamcham. It is suggest to make Chamcham using the following ingradients.

\section{References}

Aggarwala, A.C. and Sharma, R.M. 1961. A laboratory manual of milk inspection printed in India by Z. T. Bandkwala at leaders press private limited, Bombay and Published by P: S. Jayusingue, $4^{\text {th }} \mathrm{Ed}$. Asia publishing house Bombay, India.

Association of Official Agricultural Chemists. AOAC. 2003. Official Methods of Analysis $17^{\star}$ Ed, Washington D.C, U.S.A.

Aneja, R.P. 1990. Processing and distribution of buffalo milk. Proceedings of the international dairy congress, Montreal. 23(1): 386396.

Arora, K. L., Dharam, P., Verma, B.B., Rajorhia, G.S., Garg, F.C. and Patil, G.R. 1995. Shelf life prediction model for rasogolla manufactured in Bikaner. Indian Journal of Dairy Science, 48(1): 50-56.

FAO. 1997. Milk, Cheese and other Livestock Products. FAO Production Year Book Rome. Italy. 51: 218.

Government Erstwhile East Planning Dept. 1998. Fourth Plan Study No. 3. Estimation of Livestock and Poultry Population and their products. Agril. Section. p. 34.

Gupta, S.K., Patel, A.A., Patil, G.R., Desai, H.K. and Ghosh, B.C. 1993. Texture Studies on selected Indian dairy products; composition, texture relationships. International Dairy Federation Special Issue. 2: 176-182.

.Katara, R.V. and Bhargava, V.N. 1990. Studies of the manufacture of Rasogolla from buffalo and soy milk blends. Indian of Dairy Science. 47(11): 981-986.

Steel, R.G.D. and Torrie, J.H. 1980. Principles and Procedures of Statistics. $2^{\text {nd }}$ Edition, McGraw Hill Book Co., New York, U.S.A. 